\title{
Seasonal Vegetative Establishment and Shoot Reserves of Eastern Gamagrass
}

Abstract

Seasonal vegetative establishment and shoot reserves of eastern gamagrass were studied at Woodward, Oklahoma. Single shoots and compound shoots were separated from parent plants and field transplanted twice monthly from January 1977 through September 1978. Shoot reserves were estimated by measurements of mass and percent new growth under etiolation, percent dry matter, and amount and percent total nonstructural carbohydrate (TNC). Etiolated growth, percent dry matter, and TNC were greatest during the winter dormant season and least during May and June. Stand establishment from vegetative propagation followed these same trends, indicating the importance of shoot reserves to vegetative propagation. Etiolated growth followed the same seasonal trends as TNC in shoots but had higher values, indicating that reserves other than carbohydrates measured in the TNC analysis may be important in new shoot growth of eastern gamagrass. Single shoots with high dry weights contained greater amounts of reserves than shoots with low dry weight sampled during the same period. Stand establishment was higher for compound than for single shoots from late June through September, apparently because compound shoots weighed more and contained more reserves than single shoots. Shoots of eastern gamagrass transplanted during the winter dormant season resulted in 90-100\% establishment. Vegetative propagation could become an important means of establishing eastern gamagrass if suitable field transplanting equipment were developed. Eastern gamagrass has the potential to become a leading forage producer and engineering research to develop suitable propagation equipment is justified.

Eastern gamagrass [Tripsacum dactyloides (L.) L.] is a highly productive and extremely palatable forage grass (Magoffin 1843, Rechenthin 1951). Hitchcock and Clothier (1899) attributed the lack of importance of this robust forage grass to its sparseness. Low seed yields, inferior seed quality, establishment difficulties, and lack of persistence under improper grazing contribute to the low limited extent of its culture as a forage grass (Killebrew 1878; Wilcox and Smith 1905; Polk and Adcock 1964; Ahring and Frank 1968). Despite the forage potential of gamagrass, few research data are available to help overcome problems associated with stand establishment. Vegetative propagation offers a possible solution to establishment problems encountered with seed. Our objective was to determine the pattern of seasonal establishment from vegetative shoots as related to organic reserves in gamagrass shoots. These food reserves are important for growth and regrowth of perennial plants following dormancy, defoliation, or other stress conditions (Sosebee and Wiebe 1971). Some stress is involved when shoots are transplanted and the relationship of shoot reserves to success of establishment might be critical.

\section{Materials and Methods}

\section{Plant Materials}

All shoots used in this study were obtained from plants of eastern gamagrass accession WW-1002 that had been established

Authors are research agronomist and research range scientist, U.S. Dep. Agr., SEA-Agr. Res. Southern Plains Range Research Station, Woodward, Oklahoma 73801 .

Manuscript received January 2, 1980. vegetatively at Woodward, Oklahoma, in June 1975 (Dewald and Louthan 1979). The plants grew undisturbed in the field during the 1976-77 growing seasons. The number of vegetative shoots per plant crown ranged from 121 to 250 (Avg. 172) during November 1976 through May 1977 and from 212 to 381 (Avg. 309) during June through October 1977. Single shoots with 1 to 4 roots and rooted compound shoots with 2 to 4 unrooted secondary shoots (Fig. 1) were hand separated from whole plant crowns and randomly placed into various trials on each study date.

\section{Vegetative Establishment}

Vegetative plantings were made twice monthly from November 1976 through October 1977. Shoots were transplanted in the field on the same day they were dug and separated from the parent plant crown. Five single shoots and five compound shoots were transplanted in four replications on each planting date. The roots of each shoot were trimmed to a length of $7.5 \mathrm{~cm}$. Each shoot was field planted in an upright position with the shoot base $7.5 \mathrm{~cm}$ below ground level in a Carey silt loam soil (Thermic Typic Argiustolls). Shoots were planted $45 \mathrm{~cm}$ apart in $91 \mathrm{~cm}$ rows in a completely randomized block design. Shoots were watered by hand immediately after planting and soil moisture was maintained by irrigation as required to bring the total precipitation equivalency up to

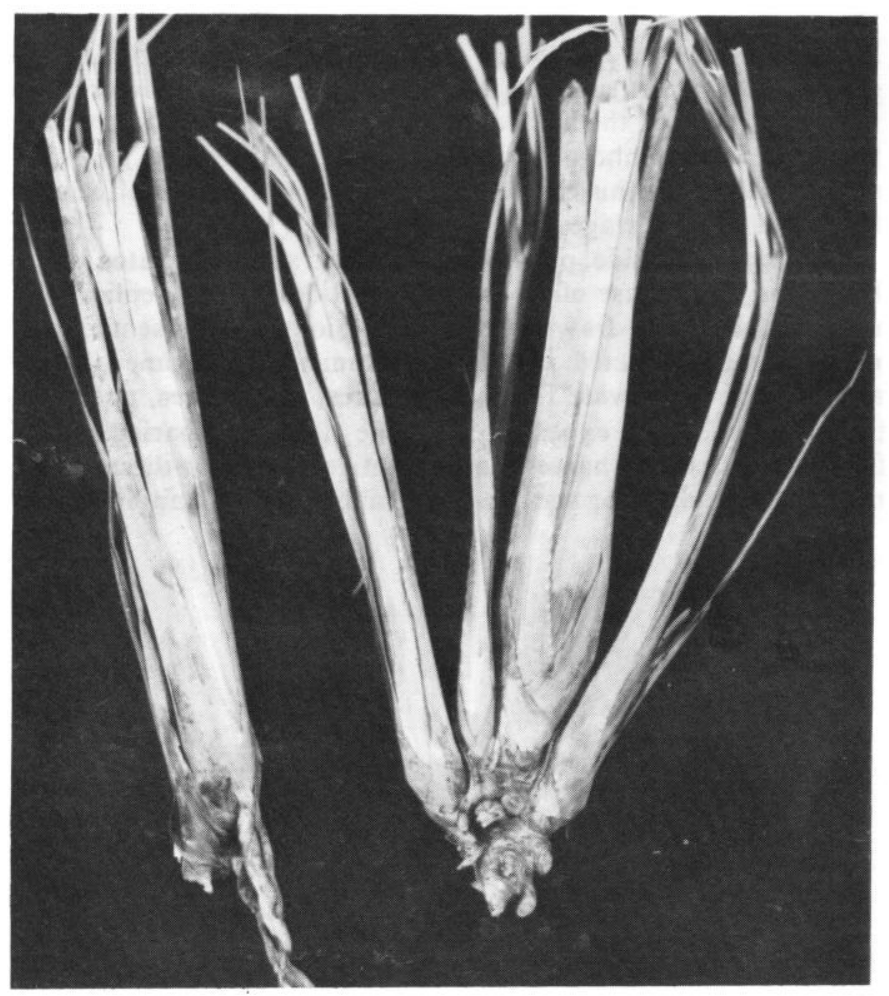

Fig. 1. Structural components of the shoot system of eastern gamagrass used in the vegetative propagation study: (a) single shoots and (b) compound shoots. 


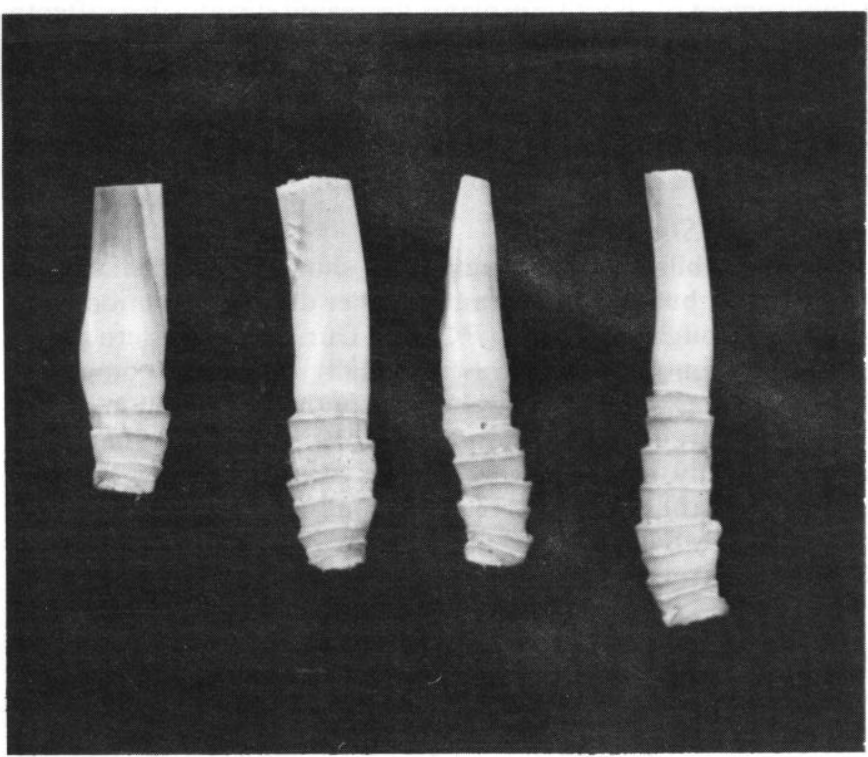

Fig. 2. Single shoots of eastern gamagrass processed to remove mature leaves at the junction of the node and sheath base. These samples were then used in organic reserve studies.
$7.5 \mathrm{~cm}$ per 10 -day period throughout the growing season. Live plant counts were recorded June 28, 1978, and are reported here as percent establishment.

\section{Shoot Reserves}

Organic reserves were determined on shoots collected twice monthly throughout 1977 and about every 20 days from late March through early September 1978. Etiolated growth, seasonal dry matter, and total nonstructural carbohydrates (TNC) were determined on single shoots that were processed (Fig. 2); mature leaves were removed at the junction of the node and sheath base of mature phytomers (Dewald and Louthan 1979). For uniformity, shoot tops were cut off $3.8 \mathrm{~cm}$ above the uppermost mature phytomer node and roots were severed at the stem base. Mature phytomer numbers ranged from 2 to 10 (Avg. 5.3) per shoot throughout this study. At each sampling date 40 to 80 shoots were alloted at random to the etiolated growth and TNC studies.

Shoots were submerged in water for about 2 hrs during the time of processing to prevent desiccation and to allow imbibition to saturation. They were then blotted with paper towels until the surface was dry and weighed immediately to obtain a saturated weight. Percentage dry matter was obtained by dividing oven-dry weight by saturated weight and multiplying by 100 .

In etiolated growth studies the basal $8.5 \mathrm{~cm}$ of shoots were individually wrapped in folded paper towels and placed in distilled water that was 3 to $4 \mathrm{~cm}$ deep. The paper towels served as a wick and kept the shoots moist during the etiolation period. Shoots were then placed in a growth chamber at $24^{\circ} \mathrm{C}$ and allowed to grow in

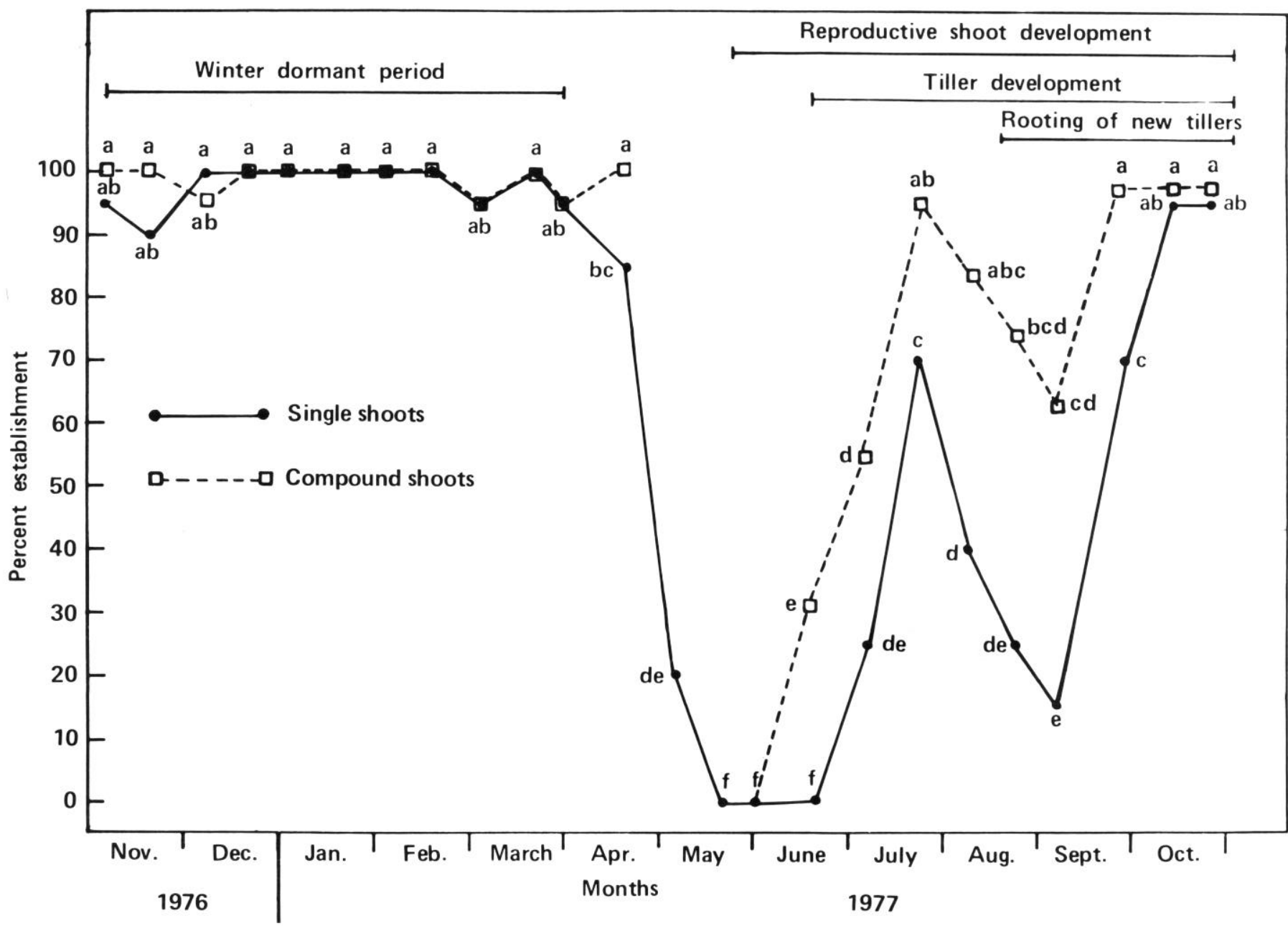

Fig. 3. Stand establishment of single and compound shoots of eastern gamagrass transplanted in the field twice monthly from November 1976 through October 1977. Compound shoots were not available for trials during May. Points on the same line having a common letter are not

significantly different at the 0.05 probability level. Compound shoots produced significantly ( $5 \%$ level t-test) better stands than single shoots in late April and from June through September. 
the dark for 35 days. At the end of the etiolation period, new top growth was separated from the shoot bases and all plant material was placed in $95 \%$ ethanol to stop further enzyme activity. The plant material was then dried at 65 to $75^{\circ} \mathrm{C}$ to a constant weight, and the new growth and shoot bases were weighed individually. Percentage new growth was obtained by dividing weight of the new growth by total shoot weight.

In TNC studies processed shoots were immeditely covered with $95 \%$ ethanol and later dried to constant weight at 65 to $75^{\circ} \mathrm{C}$ and individually weighed. Replications were formed by grouping from 3 to 6 shoots together into subsamples and grinding them through a 40-mesh screen. TNC extractions and determinations followed procedures described by Heinze and Murneek (1940), Smith et al. (1964), and Trlica and Cook (1971) with modifications described by the Association of Official Agriculture Chemists (1965).

\section{Statistical Analysis}

All data were subjected to analysis of variance, and Duncan's multiple range test was used to separate $(P<0.5)$ mean differences. Student's $t$ test was used for differences in stand establishment between single and compound shoots and in percent dry matter between etiolated and nonetiolated shoots on the same sampling dates. Linear regression correlation coefficients were determined between $\%$ dry matter and $\%$ TNC.

\section{Result and Discussion}

\section{Vegetative Establishment}

Single Shoots

Stand establishment with single shoots of eastern gamagrass was significantly better when transplanting was done during the winter dormant scason, October through March, rather than during the growing season, May through September (Fig. 3). Establishment percentages were 90 to 100,85 , and $20 \%$, respectively, from transplantings made during October through March, in mid April, and in early May. Single shoots transplanted in late May through June did not survive. Establishment increased from $25 \%$ for transplant- ings made in early June to $70 \%$ from the late July transplantings. Establishment of shoot transplants decreased steadily thereafter to a low of $15 \%$ in early September. Single shoots transplanted in late September resulted in $70 \%$ stand establishment. Transplanting single shoots of eastern gamagrass during winter quiescence or dormancy resulted in superior stand establishment over transplantings made during the growing season.

\section{Compound Shoots}

Stand establishment of compound shoots paralleled that of single shoots but was significantly higher during the period from late June through September $(P<0.05)$. During May eastern gamagrass accession WW-1002 was essentially devoid of compound shoots for transplanting (Dewald and Louthan 1979). Stand establishments from compound shoots were $30 \%$ from mid June, $55 \%$ from early July, and 95\% from mid July transplantings. Thereafter, stand establishment decreased steadily and was significantly lower for early September transplantings. Establishment from late September through late April was 95 to $100 \%$.

\section{Shoot Reserves \\ Etiolated Growth}

We consider etiolated growth (new growth of shoots in dark without energy inputs from photosynthesis) as a good indicator of organic reserves. In 1977 dry weights of new etiolated growth were significantly lower from mid-April through June than on other sampling dates. Etiolated growth weight was greater during October through March than during April through September, 1977 , and significantly so on 9 of the 11 sampling dates. Dry weight of new etiolated growth was significantly greater on March 30, 1978, than on any other sampling date. In 1978 the dry weights of new ctiolated growth were lowest in late May or about 2 weeks later than in 1977. Possibly organic reserves in shoots at the beginning of the growing season were higher in 1978 than in 1977.

The percent of the total etiolated dry shoot weight that was new top growth followed the same general pattern as did the dry weight of new etiolated growth (Fig. 4). Percentages of new etiolated top

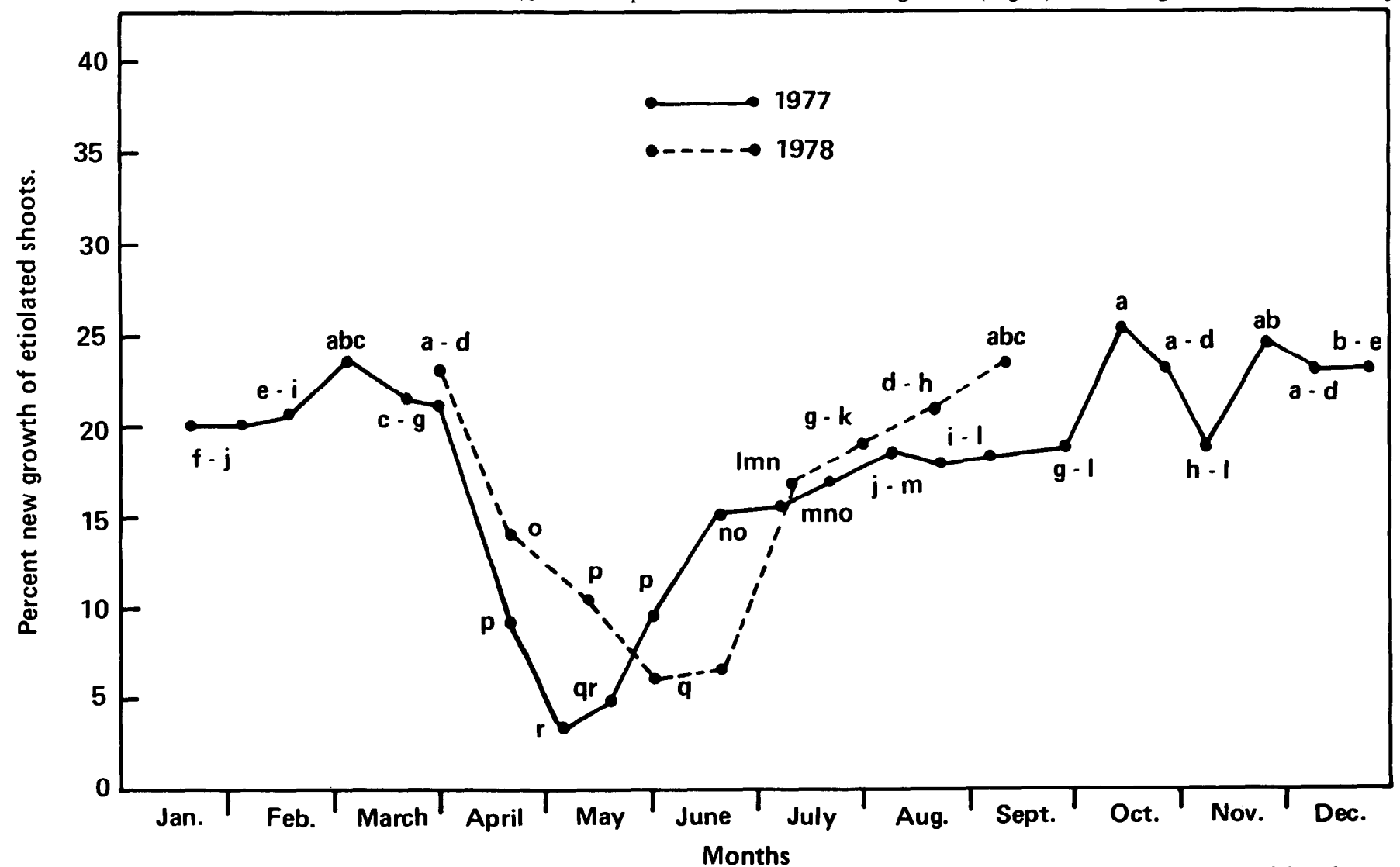

Fig. 4. Etiolated growth of single shoots of eastern gamagrass from field collections made twice monthly during 1977 and about every 20 days from late March through early September 1978. Points on both lines having a common letter are not significantly different $(P \leq 0.05)$. 
growth were significantly lower on May 5 and 19, 1977, and May 31 and June 20, 1978, than on any other sampling dates.

\section{Dry Matter}

Organic reserves, a component of dry matter, is at least partially responsible for scasonal fluctuations in amount and \% dry matter. The percentage dry matter of etiolated eastern gamagrass shoots was significantly greater during winter dormancy (October through March) than during the growing season (April through Scptember) in both 1977 and 1978. Percentages of shoot dry matter were significantly lower from May 19 to June 10, 1977, and from May 31 and July 10, 1978, than at other dates.

Percentage dry matter of non-etiolated shoots sampled during November and December, 1977, and from March 31 through September 11, 1978, was significantly $(P<0.01)$ greater $(6$ to $9 \%)$ than that of etiolated shoots for the same dates (Fig. 5). This could be expected since respiration continued during the etiolation period, and non-etiolated shoots were fixed in $95 \%$ ethanol on the sampling dates. The percentage difference is contributed to energy losses through respiration during etiolation.

\section{Total Nonstructural Carbohydrate}

TNC and dry matter in shoots of eastern gamagrass had similar seasonal cyclic trends. A regression analysis was made on data from 108 shoot samples collected on 13 dates during November and December, 1977, and from March 31 through September 11, 1978. The regression equation for $\% \mathrm{TNC}(\mathrm{Y})$ and $\% \mathrm{DM}(\mathrm{X})$ on a saturated weight basis was $-2.678+0.186 \mathrm{~S}\left(R^{2}=0.80, R<0.0001\right)$. When Wolf (1978) calculated regression coefficients between $\%$ TNC and \% DM of saturated $10 \mathrm{~cm}$ segments of alfalfa (Medicago sativa L.) roots in several experiments the regression equation was $-13.2+0.70 \mathrm{X}$ with $R^{2}$ values ranging from 0.70 to 0.96 . We would not necessarily expect agreement in these coefficients because of differences in TNC analysis methods, species, and plant parts analyzed.
Average TNC per shoot increased from $340 \mathrm{mg}$ in early November to $590 \mathrm{mg}$ in late December and decreased from $460 \mathrm{mg}$ on March 31 to lows of 50,70 , and $90 \mathrm{mg}$ TNC per shoot on May 31 , June 20, and July 10, 1978, respectively. Amount of TNC increased somewhat to 130,110 , and $130 \mathrm{mg}$ on July 31, August 21, and September 11,1978, respectively, but these values were considerably lower than those made on sampling dates during the winter dormant season.

Percentage TNC increased significantly from about $11 \%$ in early November to over $18 \%$ in late December, 1977 (Fig. 6). Probably that increase could be attributed to translocation from other plant parts. If top growth, leaf blades, upper sheath tissue and/or culms are the TNC source, then grazing or removal of top growth during November or early December would reduce the supply of TNC to the shoot base. Meristematic tissue (leaf primordia and lateral buds) necessary for renewed top growth is located in the shoot basc of most perennial grasses. Management treatments that reduce TNC of the shoot base could also reduce plant vigor and subsequent forage production.

On March 31,1978 , about $12 \%$ of the processed shoot weight was TNC but the percentage declined to a low of less than $5 \%$ on May 31,1978 . Thereafter, TNC ranged from about $6 \%$ on June 20 to over $9 \%$ on September 11, 1978.

Low organic reserve concentrations in shoot bases of castern gamagrass during May and June probably reflects shifts in morphological development, growth requirements, and other factors. These data suggest that during this critical period management would be especially important for sustained forage production and stand persistence.

\section{Conclusions}

All parameters measured (shoot establishment potential, etiolated growth, dry matter and TNC in shoots) were higher during

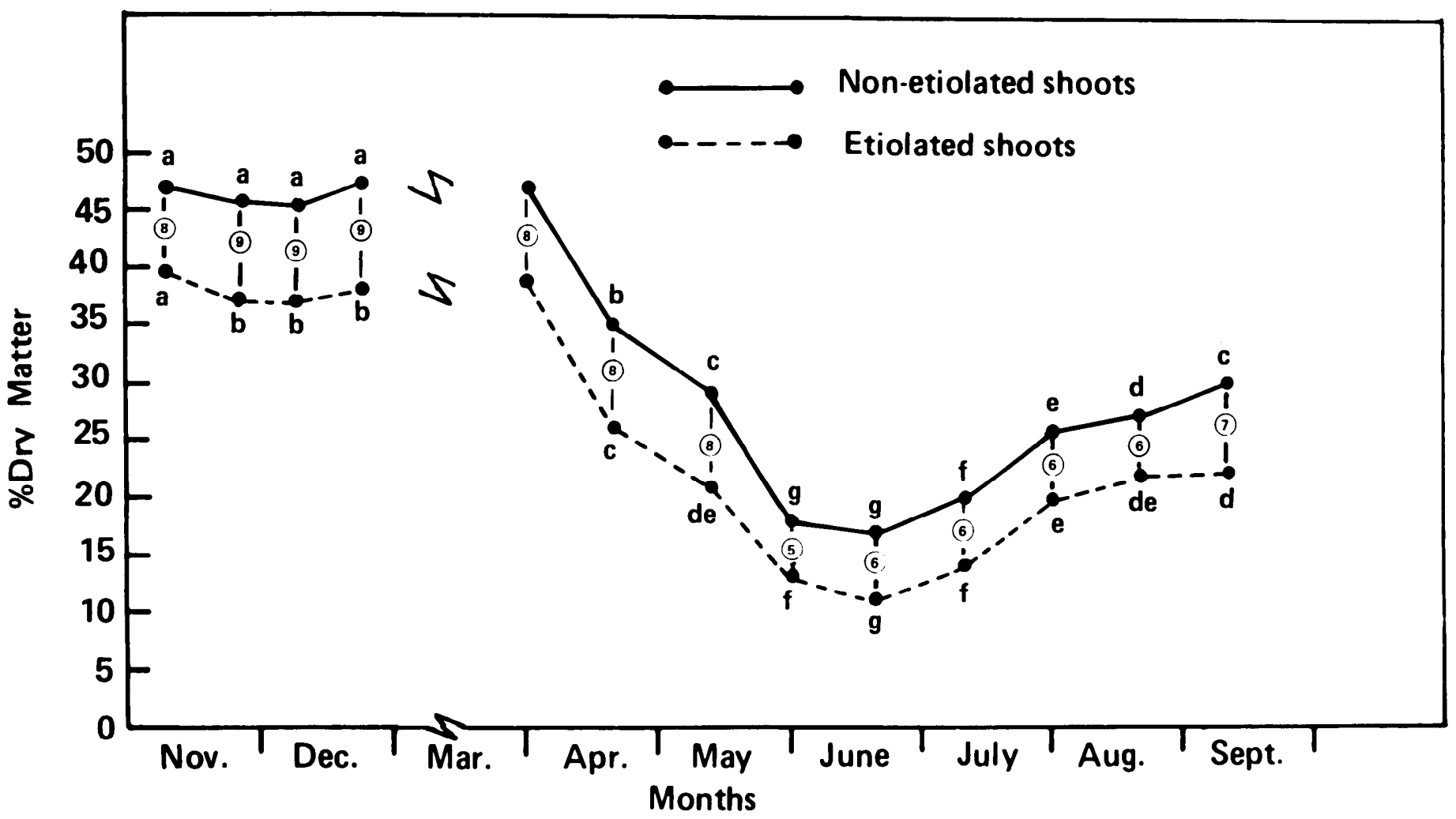

Fig. 5. Percent dry matter of single shoots of eastern gamagrass grown under etiolation were compared to non-etiolated shoots. Numbers in circles are the differences in percentage dry matter between etiolated and non-etiolated shoots on the respective dates. Points on the same line having a common letter are not significantly different $(P \leq 0.05)$. Nonetiolated shoots were significantly higher $(P \leq 0.001)$ in percent dry matter than etiolated shoots on all sampling dates. 


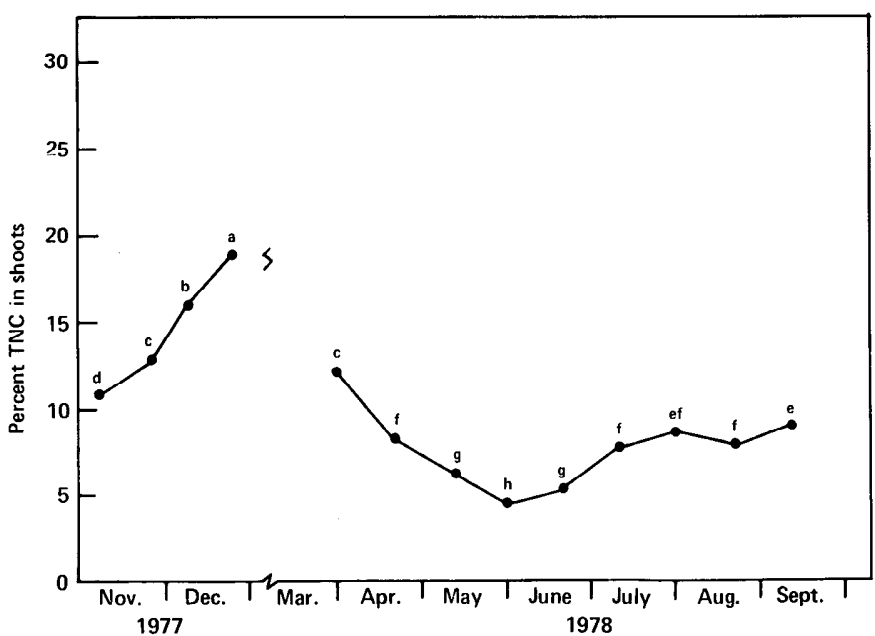

Fig. 6. Percent TNC of single shoots of eastern gamagrass at various dates during November and December 1977 and from March 31 through September 11, 1978. Points having a common letter are not significantly different at the 0.05 probability level.

the winter dormant season than during the growing season and were lowest during May and June. Shoot reserves were closely involved with the establishment of vegetative transplants.

Although the amount and percent of new etiolated growth followed the same seasonal trend as amount and percentage of TNC in shoots, the mass of etiolated growth was usually considerably higher. This indicated that reserves other than carbohydrates, or at least other than the carbohydrates measured in the TNC analysis, may be important in eastern gamagrass establishment and growth. Chung and Trlica (1980) found that labile products other than TNC may be important as reserves in blue grama [Bouteloua gracilis (Willd. ex H.B.K.) Lag. ex Griffiths].

Milligrams TNC per shoot varied with individual shoot weights but percentages (TNC) were uniform within sampling dates. During any period shoots with high dry weight contained greater amounts of TNC than shoots with low dry weight. The greater TNC concentration in heavier shoots probably accounts for the better stand establishment obtained with heavier compound shoots in comparison to lighter single shoots from late Junc through September.

Both single and compound shoots of eastern gamagrass were field transplanted during the winter dormant season with a 90 to $100 \%$ survivability. Vegetative propagation could be an important means of establishing eastern gamagrass if practical equipment for transplanting could be developed. The high forage potential of eastern gamagrass justifies research efforts in this direction.

\section{Literature Cited}

Ahring, R.M., and H. Frank. 1968. Establishment of eastern gamagrass from seed and vegetative propagation. J. Range Manage. 21:27-30.

Association of Official Agriculture Chemists. 1965. Official Methods of Analysis of the Association of Official Agricultural Chemists. 10th ed. Washington, D.C. p. 498-499.

Chung, H., and M.J. Trlica. 1980. ${ }^{14} \mathrm{C}$ distribution and utilization in blue grama as affected by temperature, water potential and defoliation regimes. Oecologia 47:190-195.

Dewald, C.L., and V.H. Louthan. 1979. Sequential development of shoot system components in eastern gamagrass. J. Range Manage. 32:147-151.

Heinze, P.H., and A.E. Murneek. 1940. Comparative accuracy and efficiency in determination of carbohydrates in plant material. Missouri Agr. Exp. Sta. Res. Bull. 314. 23 p.

Hitchcock, A.S., and G.L. Clothier. 1899. Native agricultural grasses of Kansas. Kansas State Agr. Coll. Bull. 87. p. 5-6.

Killebrew, J.B. 1878. The grasses of Tennessee including cereal and forage plants. The Amer. Col, Nashville, p. 107-108.

Magoffin, J. 1843. Culture of gamagrass. The Southern Cultivator 1: 103-104.

Polk, D.B., and W.L. Adcock. 1964. Eastern gamagrass. Cattleman 50:8284.

Rechenthin, C.A. 1951. Range grasses in the Southwest; Eastern gamagrass, Texas cupgrass, Pan American balsamscale and smooth cordgrass. Cattleman 38:110-112.

Smith, D., G.M. Paulsen, and C.A. Raguse. 1964. Extraction of total available carbohydrates from grass and legume tissue. Plant Physiol. 39:960-962.

Sosebee, R.E., and H.H. Wiebe. 1971. Effect of water stress and clipping on photosynthate translocation in two grasses. Agron. J. 63:14-17.

Trlica, M.J., and C.W. Cook. 1971. Defoliation effects of carbohydrate reserves of desert species. J. Range Manage. 24:418-425.

Wilcox, E.V., and C.B. Smith. 1905. Farmers Cyclopedia of Agriculture. Orange Judd. Co., N.Y. 619 p.

Wolf, D.D. 1978. Nonstructural carbohydrate and dry matter relationships in alfalfa tap roots. Crop Science 18:690-692.

CHANGE OF ADDRESS notices should be sent to the Managing Editor, 2760 West Fifth Ave., Denver, Colo. 80204 , no later than the first day of the month of issue. Copies lost due to change of address cannot be replaced unless adequate notice is given. To assure uninterrupted service, provide your local postmaster with a Change of Address Order (POD Form 3575) indicating thereon to guarantee forwarding postage for second-class mail. 